\title{
Development of an ecotoxicological protocol for the deep- sea fauna using the hydrothermal vent shrimp Rimicaris exoculata
}

\author{
Auguste M. ${ }^{1}$, Mestre N.C. ${ }^{1,}{ }^{*}$, Rocha T.L ${ }^{1}$, Cardoso C. ${ }^{1}$, Cueff-Gauchard Valerie ${ }^{2}$, Le Bloa Simon ${ }^{2}$, \\ Cambon-Bonavita Marie-Anne ${ }^{2}$, Shillito B. ${ }^{3}$, Zbinden M. ${ }^{3}$, Ravaux J. ${ }^{3}$, Bebianno M.J. ${ }^{1}$
}

${ }^{1}$ CIMA, Faculty of Science and Technology, University of Algarve, Campus de Gambelas, 8005139

Faro, Portugal

2 Ifremer, REM/EEP/Laboratoire de Microbiologie des Environnements Extrêmes, UMR 6197, UBO,

CNRS, Technopôle Brest Iroise, CS10070, Plouzané, France

${ }^{3}$ Sorbonne Universités, UPMC Univ Paris 06, UMR CNRS 7208, MNHN/IRD-207/UCN/UA, Biologie des

Organismes et Ecosystèmes Aquatiques", 7 Quai St Bernard, 75252 Cedex 5 Paris, France

* Corresponding author : N. C. Mestre, email address : neliamestre@gmail.com

\begin{abstract}
:
In light of deep-sea mining industry development, particularly interested in massive-sulphide deposits enriched in metals with high commercial value, efforts are increasing to better understand potential environmental impacts to local fauna. The aim of this study was to assess the natural background levels of biomarkers in the hydrothermal vent shrimp Rimicaris exoculata and their responses to copper exposure at in situ pressure (30 MPa) as well as the effects of depressurization and pressurization of the high-pressure aquarium IPOCAMP. $R$. exoculata were collected from the chimney walls of the hydrothermal vent site TAG (Mid Atlantic Ridge) at $3630 \mathrm{~m}$ depth during the BICOSE cruise in 2014. Tissue metal accumulation was quantified in different tissues (gills, hepatopancreas and muscle) and a battery of biomarkers was measured: metal exposure (metallothioneins), oxidative stress (catalase, superoxide dismutase, glutathione-S-transferase and glutathione peroxidase) and oxidative damage (lipid peroxidation). Data show a higher concentration of $\mathrm{Cu}$ in the hepatopancreas and a slight increase in the gills after incubations (for both exposed groups). Significant induction of metallothioneins was observed in the gills of shrimps exposed to $4 \mu \mathrm{M}$ of $\mathrm{Cu}$ compared to the control group. Moreover, activities of enzymes were detected for the in situ group, showing a background protection against metal toxicity. Results suggest that the proposed method, including a physiologically critical step of pressurizing and depressurizing the test chamber to enable the seawater exchange during exposure to contaminants, is not affecting metal accumulation and biomarkers response and may prove a useful method to assess toxicity of contaminants in deep-sea species.
\end{abstract}




\section{Graphical abstract}

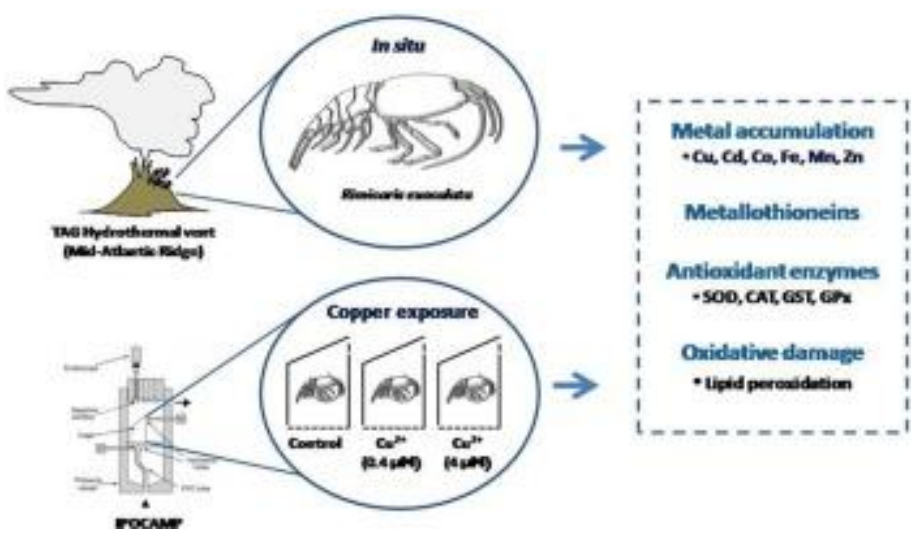

\section{Highlights}

- Rimicaris exoculata have developed antioxidant defences to cope with a metal-rich habitat. The depressurization of the test chamber every $12 \mathrm{~h}$ did not affect the biomarkers response. The proposed method seems useful to assess toxicity to contaminants in deep-sea species.

Keywords : Deep-sea mining; hydrothermal vents; biomarkers; IPOCAMP; copper; TAG

\section{Introduction}

Hydrothermal vents are massive sulphide deposits with high concentration of various metals (e.g. Cu, $\mathrm{Ni}, \mathrm{Zn}, \mathrm{Mn}, \mathrm{Co}, \mathrm{Ag}, \mathrm{Au}$ ) with potential economic interest to 
Guinea has given exploration license to Nautilus Minerals Corporation to explore this type of mineral deposits in the Manus basin (Gena 2013). However, it is likely that the impact of human activities will somehow change the natural equilibrium of this particular environment (Van Dover 2014). The living fauna will likely be exposed to variations in environmental metal composition, hence the need to further explore the toxicity of chemicals associated with deep-sea exploitation. For this it is considered essential to adapt the existing ecotoxicological protocols from shallow-water to the deep-sea conditions to enable a better understanding of potential anthropogenic impact on deep-sea fauna (Mestre et al. 2014).

The Trans-Atlantic Geotraverse (TAG) hydrothermal vent field is located on the Mid-Atlantic Ridge and its hot fluids are rich in various metals, including copper with concentrations ranging between 120 and $150 \mu \mathrm{M}$ (Edmonds et al. 1996). Copper is an essential trace element found in a variety of cells and tissues and used as cofactor of several enzymes. However, free $\mathrm{Cu}$ ions $\left(\mathrm{Cu}^{+}\right.$and $\left.\mathrm{Cu}^{2+}\right)$ can participate in the formation of reactive oxygen species (ROS) (Gaetke and Chow 2003). As invertebrates possess the ability to concentrate certain metals from the surrounding medium, reflecting the variation in metal concentration in the environment (White and Rainbow 1985), they are useful tools to monitor change of metal amounts as a result of anthropogenic activities.

Increasing total dissolved metal concentration will lead to a higher metal uptake rate (Rainbow 1998). To prevent the increase of metal accumulation in cells, organisms possess defence mechanisms such as specific proteins which play a role in binding metals, as for example the metallothioneins (MTs). These cysteine-rich non-enzymatic proteins are vital for various biological functions like storage, transport, compartmentalization of essential and non-essential metals (detoxification mechanisms) and can also act as oxyradicals scavengers protecting cells against ROS (Roesijadi 1992). In the presence of certain metals and/or high-metals concentrations, ROS formation will induce an antioxidant defence mechanism. This mechanism consists in the action of specific enzymatic proteins, such as superoxide dismutase (SOD), catalase (CAT), glutathione peroxidase (GPx) and glutathione-s-transferase (GST). These enzymes will limit the ROS levels and prevent oxidative damage (Di Giulio et al. 1995). Nevertheless, if the action of these enzymes is not sufficient, the free radicals will reach the cellular membranes and cause oxidative damage, such as lipid peroxidation (LPO), 
which is the oxidation of polyunsaturated fatty acids (PUFAs; Halliwell and Gutteridge 1984).

Previous studies have already looked into metal accumulation and antioxidant responses in the deep-sea hydrothermal vent mussel Bathymodiolus azoricus from Menez-Gwen, Lucky Strike and Rainbow vent sites (Company et al. 2004, 2006a,b, 2007, 2008, Bebianno et al. 2005). A few studies have looked into metal accumulation (Kádár et al. 2006, Geret et al. 2002), antioxidant enzymes activities (Gonzalez-Rey et al. 2008), MTs and oxidative damage (Geret et al. 2002, Gonzalez-Rey et al. 2007) in the vent shrimp Rimicaris exoculata. Nevertheless, only one study has investigated the toxicity of metal exposure under laboratory controlled deep-sea conditions of high pressure and low temperature (Company et al. 2006a) using one of the few available equipment that enable these kind of studies, the IPOCAMP (Incubateur Pressurisé pour l'Observation et la Culture d'Animaux Marins Profonds; Shillito et al. 2014).

The chimney walls at TAG are covered by dense swarms (1200-3000 indiv. $\left.\mathrm{m}^{-2}\right)$ of the vent shrimp R. exoculata, also known to be one of the most abundant invertebrate species in the Mid-Atlantic Ridge (Desbruyères et al. 2000, Schmidt et al. 2008). $R$. exoculata is also one of the most studied deep-sea species, making it a good model for investigating deep-sea environmental changes (e.g. Van Dover et al. 1988, Gebruk et al. 1993, Vereshchaka 1997, Rieley et al. 1999, Allen et al. 2001, Geret et al. 2002, Ravaux et al. 2003, Zbinden et al. 2004, 2008, Copley et al. 2007, Gonzalez-Rey et al. 2007, 2008, Anderson et al. 2008, Corbari et al. 2008, Schmidt et al. 2008, 2009, Cottin et al. 2010, Ponsard et al. 2013, Jan et al. 2015).

Elutriate toxicity tests with weathered vent chimney material were conducted during the environmental impact studies at Solwara 1, Papua New Guinea. The concentration of $\mathrm{Cu}$ released after $30 \mathrm{~min}$ in the field-based elutriate tests was $15-20$ $\mu \mathrm{g} . \mathrm{L}^{-1}$ and in the laboratory-based tests was 38-140 $\mu \mathrm{g} . \mathrm{L}^{-1}$ (Simpson et al. 2008). The selected copper concentrations used in the present study reflect these results.

This study assesses the biomarkers (MTs, antioxidant enzymes and LPO) response in different tissues (gills, hepatopancreas and abdominal muscle) in $R$. exoculata exposed to $0.4 \mu \mathrm{M}\left(25 \mu \mathrm{g} . \mathrm{L}^{-1}\right)$ and $4 \mu \mathrm{M}\left(254 \mu \mathrm{g} . \mathrm{L}^{-1}\right)$ of copper at in situ pressure and temperature $\left(30 \mathrm{MPa}, 10^{\circ} \mathrm{C}\right)$. It also compares the metal accumulation $(\mathrm{Cu}$, $\mathrm{Zn}, \mathrm{Fe}, \mathrm{Mn}, \mathrm{Co}, \mathrm{Cd}$ ) and biomarkers baseline levels under natural conditions (isobaric 
sampling) and after maintenance in a high-pressure aquarium IPOCAMP (no metal exposure). Finally, this study also compares the effects of depressurization and pressurization of the test chamber (conditions necessary for the $\mathrm{Cu}$ enriched seawater and oxygen renewal during the test).

\section{Materials and Methods}

\subsection{Sample collection}

Rimicaris exoculata were sampled in February 2014 from the TAG vent field $\left(26^{\circ} 08.2^{\prime} \mathrm{N}, 44^{\circ} 49.5^{\prime} \mathrm{W}\right)$ in the Mid-Atlantic Ridge, during the oceanographic cruise BICOSE, aboard the research vessel Pourquoi pas?. The organisms were collected using the slurp gun of the ROV VICTOR 6000 (IFREMER), and using the PERISCOP for isobaric and isothermal recovery (Shillito et al. 2008). The shrimps were taken from the main black smoker on the wall near the main spire.

\subsection{Cu exposure experiments}

A total of 24 shrimps were used in this study, divided into 4 groups. The first group ( $\mathrm{n}=6$ ) called in situ (IS) was dissected under sterile conditions and flash frozen in liquid nitrogen straight after collection and stored at $-80^{\circ} \mathrm{C}$ until further use. The other shrimps were directly transferred into the pressurized aquarium IPOCAMP for a $\mathrm{Cu}$ exposure experiment at $10^{\circ} \mathrm{C}$. A copper solution was prepared using $\mathrm{CuSO}_{4}$ (analytical grade, Sigma). Shrimps ( $\mathrm{n}=6$ per condition) were isolated in $3.8 \mathrm{~L}$ boxes for: control (C; only seawater); $0.4 \mu \mathrm{M}$ of $\mathrm{Cu}(\mathrm{Cu} 1)$; and $4 \mu \mathrm{M}$ of $\mathrm{Cu}(\mathrm{Cu} 2)$. The experiment was carried out at $30 \mathrm{MPa}$ and $10^{\circ} \mathrm{C}$ for $72 \mathrm{~h}$. For seawater and oxygen renewal, the IPOCAMP was depressurized every $12 \mathrm{~h}$, and the viability of the animals was checked. At the end of the exposure period (72 h), survival of the shrimp was $100 \%$, although one of the animals of the $\mathrm{Cu} 2$ group appeared less responsive to stimulation. The tissues were dissected (gills, hepatopancreas and muscle; without gut or exoskeleton) and immediately frozen in liquid nitrogen and stored at $-80^{\circ} \mathrm{C}$ until further analyses.

\subsection{Tissue preparation}


Tissues were individually homogenized at $4^{\circ} \mathrm{C}$ in a Tris- $\mathrm{HCl}\left(0.02 \mathrm{M}, 5 \mathrm{ml} . \mathrm{g}^{-1}\right.$ soft tissue) buffer with butylated hydroxytoluene (BHT, $10 \mu 1 . \mathrm{mL}^{-1}$ ), $\mathrm{pH}$ 8.6. The homogenate $(3 \mathrm{ml})$ was separated in soluble and insoluble fractions by centrifugation $\left(30000 \times \mathrm{g}, 30 \mathrm{~min}, 4^{\circ} \mathrm{C}\right)$ and the remaining homogenate was used for determination of metal concentrations. After centrifugation, a part of the supernatant was used for the measurement of LPO and total protein content. A second centrifugation $(30000 \times \mathrm{g}, 30$ min, $4^{\circ} \mathrm{C}$ ) separated the low molecular weight proteins, and the supernatant was used for MT measurements.

For antioxidant enzyme analysis, tissues were individually homogenized in 50 $\mathrm{mM}$ Tris-HCl buffer, $\mathrm{pH} 7.6$, containing sucrose (250 mM), $\mathrm{MgCl}_{2}(5 \mathrm{mM})$, DTT (1 $\mathrm{mM}$ ). After $10 \mathrm{~min}$ of incubation, the homogenates were centrifuged at $1000 \times \mathrm{g}$ for 10 $\min$ at $4^{\circ} \mathrm{C}$ and the cytosolic fraction was kept for analysis.

\subsection{Metal analysis}

For metal concentration determination, homogenates were weighed, dried $\left(80^{\circ} \mathrm{C}\right.$, $48 \mathrm{~h}$ ) and submitted to wet acid digestion with $67 \%$ nitric acid in a hot plate $\left(80^{\circ} \mathrm{C}, 2 \mathrm{~h}\right)$. Six metals $(\mathrm{Cu}, \mathrm{Zn}, \mathrm{Fe}, \mathrm{Mn}, \mathrm{Co}, \mathrm{Cd})$ were analysed by graphite furnace absorption spectrometry (AAS, AAnalyst 800- PerkinElmer). Accuracy of the analytical method was checked by analysing certified reference material TORT-2 (NRC-CNRC) (lobster hepatopancreas), measured values $\left(99 \pm 17 \mu \mathrm{g} \cdot \mathrm{g}^{-1} \mathrm{Cu}, 138 \pm 28 \mathrm{Fe}, 124 \pm 52 \mathrm{Zn}, 14 \pm 2\right.$ $\mathrm{Mn}, 0.49 \pm 0.08 \mathrm{Co}, 33 \pm 3 \mathrm{Cd}$ ) were within the values of certified values in the reference material $\left(106 \pm 10 \mu \mathrm{g} \cdot \mathrm{g}^{-1} \mathrm{Cu}, 105 \pm 13 \mathrm{Fe}, 180 \pm 6 \mathrm{Zn}, 13.6 \pm 1.2 \mathrm{Mn}\right.$, $0.51 \pm 0.09 \mathrm{Co}, 26.7 \pm 0.6 \mathrm{Cd}$ ). Data expressed as $\mu \mathrm{g} . \mathrm{g}^{-1}$ of dry tissue weight (d.w.). The values for total soft tissues correspond to the sum of gills, hepatopancreas and muscle, taking into the account the contribution of the weight of each tissue.

\subsection{Metallothioneins (MTs)}

MTs were determined in the heat-stable supernatant by differential normal pulse polarography (Bebianno and Langston 1989), using an Eco Chemie mAutolab III potentiostat and a Methrom 663VA stand with a static mercury drop electrode (SMDE) and GPES 4.9 software (Eco Chemie). In the absence of a shrimp MT standard, a rabbit MT standard was used. MTs levels are expressed in $\mu \mathrm{g} \mathrm{g}^{-1}$ of wet tissue weight (w.w.). 


\subsection{Total proteins}

Total proteins were measured by the method of Bradford et al. (1976) adapted to a microplate reader (Infinite ${ }^{\circledR} 200$ PRO-Tecan), using Bovine Serum Albumin (SigmaAldrich) as a standard. The proteins concentration is expressed as $\mathrm{mg} \cdot \mathrm{g}^{-1}$ of wet tissue weight.

\subsection{Antioxidant enzymes activities}

Superoxide dismutase (SOD) activity was determined by measuring the reduction of cytochrome $\mathrm{c}$ by the xanthine oxidase/hypoxanthine system at $550 \mathrm{~nm}$ (McCord and Fridovich 1969). One unit of SOD is defined as the amount of enzyme that inhibits the reduction of cytochrome c by $50 \%$. SOD activity is expressed in $\mathrm{U}_{\mathrm{mg}} \mathrm{m}^{-1}$ prot.

Catalase (CAT) activity was determined according to Greenwald (1985). The activity was determined as the decrease in absorbance during $1 \mathrm{~min}$ at $240 \mathrm{~nm}$ due to $\mathrm{H}_{2} \mathrm{O}_{2}$ consumption in buffer of monobasic and dibasic potassium, $\mathrm{pH}$ 7.5. CAT activity is expressed as $\mu$ mol. $\mathrm{min}^{-1} . \mathrm{mg}^{-1}$ prot.

Gluthatione peroxidation (GPx) activity was measured by following NADPH oxidation at $340 \mathrm{~nm}$ in the presence of excess glutathione reductase, reduced glutathione and corresponding peroxide (Flohe and Gunzler 1984). The GPx activities were measured by using cumene hydroperoxide as substrate. GPx activity is expressed as nmol. $\mathrm{min}^{-1} \cdot \mathrm{mg}^{-1}$ prot.

Gluthatione-S-transferase (GST) activity was determined by following the conjugation of reduced gluthatione (GSH) with 1-chloro-2,4-dinitrobenzene (CDNB; Habig et al. 1974). A buffer containing $\mathrm{KH}_{2} \mathrm{PO}_{4} / \mathrm{K}_{2} \mathrm{HPO}_{4}(0.2 \mathrm{M})$, pH 7.9, was used. The change in absorbance was recorded at $340 \mathrm{~nm}$ for $1 \mathrm{~min}$. The activity was calculated as nmol of CDNB formed per $\min ^{-1} \cdot \mathrm{mg}^{-1}$ prot (using a molar extinction coefficient of $\left.9.6 \mathrm{mM}^{-1} \cdot \mathrm{cm}^{-1}\right)$.

\subsection{Lipid peroxidation (LPO)}


Oxidative damage was analysed in terms of LPO. Determination of malondialdehyde (MDA) and 4-hydroxyalkenals (4-HNE) concentration, both subproducts of polyunsaturated fatty acid peroxidation, was realized using the method described by Erdelmeier et al. (1998) and maximal absorbance at $586 \mathrm{~nm}$. Malondialdehyde bis-(dimethyl acetal) (Sigma-Aldrich) was used as a standard. The LPO is expressed in nmol of MDA + 4-HNE $\mathrm{mg}^{-1}$ prot.

\subsection{Statistical analysis}

The non-parametric Kruskall-Wallis test was used to assess the significant differences between exposure groups and tissues for each variable (biomarkers and metals concentration). Results were significantly different when $p<0.05$. Principal components analysis (PCA) was used in the ordination method to evaluate the relationship between the different treatments and the analysed variables in the gills and the hepatopancreas.

\section{Result and Discussion}

\subsection{Metal accumulation}

The baseline metals concentrations in $R$. exoculata collected from TAG for the different tissues are described in the Table 1. In all tissues the metal concentration descending trend is the following $\mathrm{Fe}>\mathrm{Cu}>\mathrm{Zn}>\mathrm{Mn}$. In the total soft tissues, gills and muscle Co is more abundant than $\mathrm{Cd}$, and the opposite was noted in the hepatopancreas (Table 1). The TAG black smoker presents hot fluids rich in metals (Fe $5590 \mu \mathrm{M}, \mathrm{Cu}$ 120-150 $\mu \mathrm{M}$, Zn $46 \mu \mathrm{M}$, Mn $680 \mu \mathrm{M}$, Co $<2 \mu \mathrm{M}$, Cd $66 \mathrm{nM})$ what is reflected by the accumulation of these metals in $R$. exoculata tissues (Table 1). This is in agreement with previous studies, with the same species but from another Mid-Atlantic Ridge vent field - Rainbow (hot fluids metal contents: Fe $24000 \mu \mathrm{M}, \mathrm{Cu} 140 \mu \mathrm{M}, \mathrm{Zn} 160 \mu \mathrm{M}, \mathrm{Mn}$ $2250 \mu \mathrm{M}$, Co $13 \mu \mathrm{M}, \mathrm{Cd} 130 \mathrm{nM}$; Douville et al. 2002). At both sites, the concentration of metals in different tissues is coherent with the variation of metals in the hot fluids. Rainbow's hot fluid is much richer in iron than TAG's fluid and iron accumulation is 
higher in shrimp's gills from the Rainbow vent site (90460 $\mu \mathrm{g} \cdot \mathrm{g}^{-1}$ d.w.; Kádár et al. 2006) when compared to those from TAG (6201 $\mu \mathrm{g} \cdot \mathrm{g}^{-1} \mathrm{~d}$.w.; Table 1).

Vent shrimps do show higher natural $\mathrm{Cu}$ concentration in their body $\left(379 \mu \mathrm{g} \cdot \mathrm{g}^{-1}\right.$ d.w.) than their coastal counterparts $\left(\sim 100 \mu \mathrm{g} . \mathrm{g}^{-1}\right.$ d.w.; White and Rainbow 1985). In a review by Pourang et al. (2004), the distribution of trace elements on coastal shrimps were listed, and for $\mathrm{Cu}$, gills always show higher $\mathrm{Cu}$ concentrations, followed by hepatopancreas and then muscle. Nevertheless, in the present study, the hepatopancreas showed higher $\mathrm{Cu}$ concentration, and this observation is different from other studies where gills presented the highest concentration for the same species (Kádár et al. 2006, Geret et al. 2002). However, the present results are consistent with other studies on vent crustaceans, such as the accumulation of trace metals in the crab Bythograea thermydron where the highest $\mathrm{Cu}$ levels were found in the hepatopancreas (Cosson and Vivier 1997). The high amount of $\mathrm{Cu}$ present in the hepatopancreas can be explained by the presence of high amounts of haemocyanin, copper-sulphur containing granules and MTs. Haemocyanin is one of the main protein synthesized in this organ (could represent $50 \%$ of total protein synthesized; Viarengo and Nott 1993).

For the copper exposure experiment, $\mathrm{Cu}$ concentrations in the tissues for the different treatments are shown in the Figure 1 (see also Table A.1 in supplementary material). The results do not show significant differences between groups $(p>0.05)$, except for the zinc with higher concentrations in the gills $\left(277 \mu \mathrm{g} . \mathrm{g}^{-1} \mathrm{~d} . \mathrm{w}\right.$. $)$ and in the total soft tissues (112 $\mu \mathrm{g} . \mathrm{g}^{-1} \mathrm{~d}$.w.) of the in situ group when compared to shrimps exposed to $4 \mu \mathrm{M}$ of $\mathrm{Cu}\left(69 \mu \mathrm{g} . \mathrm{g}^{-1} \mathrm{~d}\right.$.w. and $49 \mu \mathrm{g} . \mathrm{g}^{-1} \mathrm{~d}$.w., respectively; $\left.p<0.05\right)$. For the in situ group, the concentration of $\mathrm{Co}$ and $\mathrm{Mn}$ is similar in the hepatopancreas and gills, but in the groups incubated inside the IPOCAMP there is a higher concentration in the gills. Cd is mainly accumulated in the hepatopancreas $\left(8.3 \mu \mathrm{g} . \mathrm{g}^{-1} \mathrm{~d}\right.$.w. $)$, when compared to the gills $\left(1.2 \mu \mathrm{g} . \mathrm{g}^{-1} \mathrm{~d} . \mathrm{w}\right)$ and the muscle $\left(0.15 \mu \mathrm{g} . \mathrm{g}^{-1}\right.$ d.w.; Fig. 1). As the in situ group represents the baseline concentrations, these results suggest that after incubation inside the IPOCAMP, where only $\mathrm{Cu}$ was added but not the other metals, there is a redistribution of metals among the different tissues. As some of these are essential metals, these results suggest their potential use in other biological functions in the gills, or that their excess are further eliminated/regulated through the gills.

A high variability in $\mathrm{Cu}$ concentration among the shrimp replicates was noted (Fig. 1). Still, the $\mathrm{Cu}$ concentration in the hepatopancreas decreases in the groups 
exposed to $\mathrm{Cu}\left(\mathrm{Cu} 1: 440 \mu \mathrm{g} . \mathrm{g}^{-1}\right.$ d.w., $\mathrm{Cu} 2: 810 \mu \mathrm{g} \cdot \mathrm{g}^{-1}$ d.w.) when compared to the in situ and control groups (IS: $1500 \mu \mathrm{g} \cdot \mathrm{g}^{-1}$ d.w., C: $1376 \mu \mathrm{g} \cdot \mathrm{g}^{-1}$ d.w.). On the other hand, a slight increase in $\mathrm{Cu}$ concentration is observed in the gills for the $\mathrm{Cu}$ exposed groups while a non-significant decrease in $\mathrm{Cu}$ present in the muscle is noticed ( $\mathrm{p}>0.05$; Fig. 1). Although, there is no published copper concentration values for $R$. exoculata habitat at TAG, the present results observed for the hepatopancreas suggest an elimination process during the $72 \mathrm{~h}$ incubation. Crustaceans possess $\mathrm{Cu}$ sulphur granules in the hepatopancreas and these may play a role as a detoxification mechanism. In shrimps, copper and sulphur are accumulated in the epithelial cells of the hepatopancreas as insoluble granules, thus decreasing the potential toxic effect of $\mathrm{Cu}$ present in the cytoplasm of cells (Viarengo and Nott 1993, Ahearn et al. 2004). Moreover, the total Cu amount for the two exposed groups do not show significant differences which is in favour of a potential regulation mechanism of metal metabolism by the shrimps. White and Rainbow (1982) found that Palaemon elegans are able to regulate body levels of copper up to a threshold exposure level, beyond which the metal is accumulated in direct proportion to external metal levels (up to $100 \mu \mathrm{g} . \mathrm{L}^{-1}$ for the coastal shrimp). This threshold would presumably be higher for vent shrimps as they are constantly bathed in seawater rich in metals. This regulation can result from a balance between accumulation and elimination rate.

\subsection{Metallothioneins}

The MTs levels increased in the gills of the $\mathrm{Cu}$ exposed groups when compared to control and IS, with significant differences between the control $\left(155 \mu \mathrm{g} . \mathrm{g}^{-1} \mathrm{w} . \mathrm{w}.\right)$ and Cu2 (332 $\mu$ g.g $\mathrm{g}^{-1}$ w.w.; $p<0.05$; Fig. 2). Higher amounts of MTs (400 $\mu \mathrm{g} . \mathrm{g}^{-1}$ w.w.) were observed in the hepatopancreas (Fig. 2) while the muscle had the lowest, but in both tissues no significant differences were observed between the different treatments $(p>0.05)$.

To our knowledge only two studies on MTs levels in $R$. exoculata were previously reported. The study by Geret et al. (2002) presents data of MTs per tissues for $R$. exoculata from the Rainbow hydrothermal vent field. The MT data obtained in the present study (gills: $161 \mu \mathrm{g} . \mathrm{g}^{-1}$ W.w.; muscle: $27 \mu \mathrm{g} . \mathrm{g}^{-1}$ w.w.; Fig. 2) are in the same

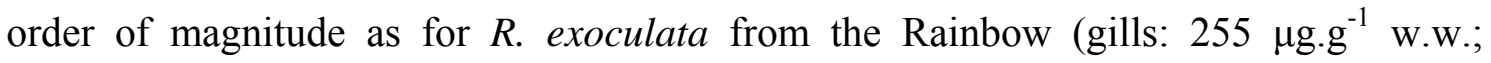


muscle: $72 \mu \mathrm{g} . \mathrm{g}^{-1}$ w.w.; Geret et al. 2002). However, TAG shrimps have lower MT levels in the hepatopancreas (399 $\mu \mathrm{g} . \mathrm{g}^{-1}$ w.w.) than those from Rainbow (3012 $\mu \mathrm{g} \cdot \mathrm{g}^{-1}$ w.w.; Geret et al. 2002). The other study that investigated MTs levels analysed the soft tissues of $R$. exoculata and Mirocaris fortunata which do not allow a direct comparison with the present, per tissue, results (Gonzalez-Rey et al. 2008).

MTs are induced in response to the $\mathrm{Cu}$ exposure. The significant induction of MTs in the gills at higher $\mathrm{Cu}$ concentration $(4 \mu \mathrm{M})$ when compared to the control group seems to follow the slight increase of $\mathrm{Cu}$ (Figs. 1 and 2). This is probably linked the role of MTs in the detoxification and/or storage of $\mathrm{Cu}$. An antioxidant role for MTs was suggested in previous studies with the mussel Mytilus galloprovincialis, through oxyradical scavenging protecting both isolated cells and the entire organism from oxidative stress (Viarengo et al. 1999). In the hepatopancreas, MTs levels do not change between groups $(p>0.05)$. Different explanations may be proposed. First, Campana et al. (2015) suggest that in the shrimp Pandalus montagui, most of the $\mathrm{Cu}$ is accumulated in a metabolically available form and excretion occurs from this component, implying that $\mathrm{Cu}$ could be eliminated in a metabolically active form and so would not induce MTs response. On the other hand, MTs can be linked to Cd, which is mainly accumulated in the hepatopancreas (Fig. 1) and whose amount does not vary after $72 \mathrm{~h}$ of incubation. The affinity of MTs with metals defines their binding abilities $(\mathrm{Cu}>\mathrm{Cd}>\mathrm{Zn}$; Engel and Brouwer 1989). Cd is a non-essential metal, thus to avoid toxicity the organisms have to limit their accumulation or to complex the accumulated metal to a non- or less-toxic form (Depledge and Rainbow 1990).

\subsection{Antioxidant enzymatic response}

The antioxidant enzymes activities show a tissue specific response and the separate analysis per tissue (not whole organism) is recommended for future studies, for higher resolution of the results. SOD activity is higher in the hepatopancreas with IS and $\mathrm{C}$ groups showing the highest values (IS: $95{\mathrm{U} . \mathrm{mg}^{-1}}^{-1}$ prot, C: $123{\mathrm{U} . \mathrm{mg}^{-1}}^{-1}$ prot; Fig. 3 ) and following the trend of $\mathrm{Cu}$ concentration (Table 1 and Fig. 1). This is in line with previous suggestions that the increase in cytosolic SOD activity is stimulated by higher $\mathrm{Cu}$ concentrations (Greco et al. 1990, Li et al. 2006). In the gills, no significant change was noted between the different treatments $(p>0.05)$. The highest GPx activity is 
observed in the hepatopancreas of the in situ group (706 nmol.min ${ }^{-1} \cdot \mathrm{mg}^{-1}$ prot; Fig. 3), which is significantly higher than in control (366 nmol. $\mathrm{min}^{-1} \cdot \mathrm{mg}^{-1}$ prot, $p<0.05$ ).

Both CAT and GST activities follow a similar pattern (Fig. 3). An increasing trend of these enzymes activities in the gills follow the increasing $\mathrm{Cu}$ concentration (IS: $1.3 \mu \mathrm{mol}$ CAT.min ${ }^{-1} . \mathrm{mg}^{-1}$ prot, $116 \mu \mathrm{mol}$ GST. $\mathrm{min}^{-1} \cdot \mathrm{mg}^{-1}$ prot, Cu2: $2.8 \mu \mathrm{mol}$ CAT.min ${ }^{-1} \cdot \mathrm{mg}^{-1}$ prot, $301 \mu \mathrm{mol} \mathrm{GST} \cdot \mathrm{min}^{-1} \cdot \mathrm{mg}^{-1}$ prot) but are not significantly different $(p>0.05)$. Increasing CAT activity with increasing $\mathrm{Cu}$ concentration has been previously observed (Li et al. 2006). Due to the low amount of tissue available, it was not possible to determine the CAT activity for the hepatopancreas. The GST activity in the hepatopancreas for the in situ group (225 $\mu \mathrm{mol} . \mathrm{min}^{-1} . \mathrm{mg}^{-1}$ prot $)$ was significantly lower when compared to the control group $\left(406 \mu \mathrm{mol} \cdot \mathrm{min}^{-1} . \mathrm{mg}^{-1}\right.$ prot, $\left.p<0.05\right)$. Moreover, for the groups placed in the IPOCAMP, a slight downward trend in GST activity was observed with increasing $\mathrm{Cu}$ concentration. CAT and GST activities in the muscle were higher for the in situ and $\mathrm{Cu} 1$ groups, with $\mathrm{Cu} 1$ significantly higher than $\mathrm{Cu} 2$ for both enzymes $(p<0.05$; Fig. 3$)$. These enzyme activities detected in the tissues of shrimps suggest a protective mechanism against the presence of ROS, as previously noted by Gonzalez-Rey et al. (2008). In their study, they found that CAT in soft tissues of shallow-water shrimps as lower activity than in vents shrimps, while higher values of SOD and GPx activities were found in shallow-water shrimps (Gonzalez-Rey et al. 2008; Table 2). When comparing the enzyme activities in the hepatopancreas, shallowwater shrimps show lower activity for GPx (8.8 and 4.71 nmol.min. $\mathrm{mg}^{-1}$.prot for $P$. serratus; Oliveira et al. 2012, Silva et al. 2013) and GST (6.4 and 3.1 nmol.min.mg${ }^{1}$.prot for $P$. serratus; Oliveira et al. 2012, Silva et al. 2013) when compared to $R$. exoculata (GPx: 804.2 nmol.min.mg ${ }^{-1}$.prot, GST: 225.6 nmol.min.mg ${ }^{-1}$.prot; Ttable 2). Similarly, $R$. exoculata presents higher values of CAT activity in the muscle $(0.55$ $\mu$ mol.min.mg ${ }^{-1}$.prot) when compared to P. elegans $\left(0.0053 \mu\right.$ mol.min. $\mathrm{mg}^{-1}$.prot for; Vinagre et al. 2014; Table 2). These observations are suggesting a detoxification strategy in this vent shrimp, adapted to an enriched metal extreme environment.

\subsection{Oxidative damage}

The LPO level in the gills of the in situ shrimps $\left(1.3 \mathrm{nmol} . \mathrm{mg}^{-1}\right.$ prot $)$ was lower than in the other groups (Fig. 4). The control group shows higher damage (2.3 nmol.mg- 
${ }^{1}$ protein) in the gills followed by a smooth decreasing trend of LPO levels with increasing $\mathrm{Cu}$ concentration ( $\mathrm{Cu} 1: 2 \mathrm{nmol} . \mathrm{mg}^{-1}$ prot, $\mathrm{Cu} 2: 1.7 \mathrm{nmol} . \mathrm{mg}^{-1}$ prot), although no significant difference was found $(p>0.05)$. LPO in the muscle is similar for the two groups exposed to $\mathrm{Cu}\left(0.50\right.$ and $0.54 \mathrm{nmol}_{\mathrm{mg}}{ }^{-1}$ prot for $\mathrm{Cu} 1$ and $\mathrm{Cu} 2$ respectively; $p>0.05$ ) while in the in situ group it is more than 1.5-fold higher than in the exposed groups (IS and $\mathrm{Cu} 1 p<0.05$ ). For the soft tissues of $R$. exoculata, from Rainbow vent, LPO was of the same order of magnitude $\left(0.3 \pm 0.05 \mathrm{nmol} . \mathrm{mg}^{-1}\right.$ prot; Gonzalez-Rey et al. 2008). These results are 3 -fold higher than that obtained for the coastal shrimps $P$. elegans and P. varians. (Gonzalez-Rey et al. 2008). Nevertheless, results suggest that $\mathrm{Cu}$, at the exposure concentrations used in this study, is not inducing lipid peroxidation in R. exoculata.

\subsection{Relationship between metal accumulation and biomarkers responses}

The present results reinforce the fact that vent fauna, especially $R$. exoculata, have developed physiological adaptive strategies to face the metal-rich habitat they live in. Moreover, the establishment of protection through the antioxidant enzymes activities seems correlated with the decreasing trend of LPO levels in the gills. The activity of enzymes seems to have a beneficial effect in decreasing the amount of ROS in cells and consequently limit the attack of ROS on membrane lipids. This result is in favour of a good detoxification process in the presence of copper. Nevertheless, the rather low impact of $4 \mu \mathrm{M}$ of $\mathrm{Cu}$ exposure on the shrimps might be due to the fact that they may have developed protective strategies as they are continuously bathed in a metal rich medium. Several studies have suggested the possibility of detoxification through the bacteria present in the gills chamber or in the gut (e.g. Jan et al. 2015). Part of the toxic compounds could be taken up by the bacteria hosted in the gills chamber of the shrimps and decreasing the amount of toxic compounds accumulated in shrimps tissues (Compère et al. 2002, Zbinden and Cambon-Bonavita 2003).

Given the small differences observed between the in situ and control groups for the variables assessed, the results suggest that the shrimps are apparently tolerant to the change of pressure (occurring during the water renewal) for at least the period of $72 \mathrm{~h}$. The proposed protocol, including the pressurization and depressurization steps of the 
high-pressure aquarium for seawater renewal, seems to be an adequate method to assess toxicity to contaminants in deep-sea species. This may enable future longer term assays under high-pressure and low-temperature conditions, which will be more realistic from the perspective of potential deep-sea mining impacts. Nevertheless, future studies should attempt to increase the samples size and also look at the effects of other contaminants likely to be released during mining activities.

\section{Conclusions}

This study gives a first appraisal of the amounts of metals, MTs, antioxidant enzymes and LPO in different tissues of the vent shrimp Rimicaris exoculata from the TAG hydrothermal vent field. $R$. exoculata shows a background protection against metal toxicity as the activities of enzymes were detected for the in situ group. A tissue specific response was observed for the biomarkers analysed. Shrimps appear to develop protection against exposure to $\mathrm{Cu}$, with increasing activity of antioxidant enzymes (CAT and GST) and induction of MT in the higher $\mathrm{Cu}$ concentration exposure $(4 \mu \mathrm{M})$. The ubiquity of the shrimp $R$. exoculata along the Mid-Atlantic Ridge and the similar responses observed in other vent sites (e.g. Rainbow) with those obtained in this study render this species as a good model for a possible monitoring of mining effects in hydrothermal vent fauna. Moreover, results suggest that the use of the pressurized aquarium do not affect the shrimps in terms of biomarkers responses to metal exposure. This method looks promising for further biomarkers responses studies with other deepsea fauna.

\section{Acknowledgements}

This work was developed under the MIDAS project (Managing impacts of deep-sea resource exploitation), funded by the European Commission 7th Framework Programme under the theme "Sustainable management of Europe's deep sea and subseafloor resources" (Grant Agreement 603418). We thank the captain and the crew of the Pourquoi pas? Vessel and ROV Victor 6000 and the chief scientist of the BICOSE cruise. MA was supported by a MER MSc grant and the French mobility grants Idex and Aquimob. 


\section{References}

Ahearn, G.A., Mandal, P.K., Mandal, A., (2004). Mechanisms of heavy-metal sequestration and detoxification in crustaceans: a review. Journal of Comparative Physiology B 174, 439-452.

Allen, C.E., Copley, J.T., Tyler, P.A., (2001). Lipid partitioning in the hydrothermal vent shrimp Rimicaris exoculata. Marine Ecology 22, 241-253.

Anderson, L., Halary, S., Lechaire, J.-P., Boudier, T., Frébourg, G., Marco, S., Zbinden, M., Gaill, F., (2008). Tomography of bacteria-mineral associations within the deep-sea hydrothermal vent shrimp Rimicaris exoculata. Comptes Rendus Chimie $11,268-280$.

Bebianno, M.J., Company, R., Serafim, A., Camus, L., Cosson, R.P., Fiala-Medioni, A., (2005). Antioxidant systems and lipid peroxidation in Bathymodiolus azoricus from Mid-Atlantic Ridge hydrothermal vent fields. Aquatic Toxicology 75, 354373.

Bebianno, M.J., Langston, W.J., (1989). Quantification of metallothioneins in marine invertebrates using differential pulse polarography. Portugaliae Electrochimica Acta 7, 511-524.

Bradford, M.M., (1976). A rapid and sensitive method for the quantification of microgram quantities of protein utilizing the principle of protein-dye binding. Analytical Biochemistry 72, 248-254.

Campana, O., Taylor, A.M., Blasco, J., Maher, W.A., Simpson, S.L., (2015).

Importance of subcellular metal partitioning and kinetics to predicting sublethal effects of copper in two deposit-feeding organisms. Environmental Science and Technology 49, 1806-14.

Company, R., Serafim, A., Cosson, R.P., Fiala-Médioni, A., Camus, L., Colaço, A., Serrão-Santos, R., Bebianno, M.J., (2008). Antioxidant biochemical responses to long-term copper exposure in Bathymodiolus azoricus from Menez-Gwen hydrothermal vent. Science of the Total Environment 389, 407-417.

Company, R., Serafim, A., Cosson, R., Fiala-Médioni, A., Dixon, D. R., Bebianno, M.J., (2007). Adaptation of the antioxidant defence system in hydrothermal-vent mussels (Bathymodiolus azoricus) transplanted between two Mid-Atlantic Ridge sites. Marine Ecology 28, 93-99.

Company, R., Serafim, A., Cosson, R., Camus, L., Shillito, B., Fiala-Medioni, A., Bebianno, M.J., (2006a). The effect of cadmium on antioxidant responses and the 
susceptibility to oxidative stress in the hydrothermal vent mussel Bathymodiolus azoricus. Marine Biology 148, 817-825.

Company, R., Serafim, A., Cosson, R., Fiala-Médioni, A., Dixon, D., Bebianno, M.J., (2006b). Temporal variation in the antioxidant defence system and lipid peroxidation in the gills and mantle of hydrothermal vent mussel Bathymodiolus azoricus. Deep Sea Research Part I: Oceanographic Research Papers 53, 11011116.

Company, R., Serafim, A., Bebianno, M.J., Cosson, R., Shillito, B., and Fiala-Medioni, A., (2004). Effect of cadmium, copper and mercury on antioxidant enzyme activities and lipid peroxidation in the gills of the hydrothermal vent mussel Bathymodiolus azoricus. Marine Environmental Research 58, 377-381.

Compère, P., Martinez, A.-S., Charmantier-Daures, M., Toullec, J.-Y., Goffinet, G., Gaill, F., (2002). Does sulphide detoxication occur in the gills of the hydrothermal vent shrimp, Rimicaris exoculata? Comptes Rendus Biologies 325, 591-596.

Copley, J.T.P., Jorgensen, P.B.K., Sohn, R.A., (2007). Assessment of decadal-scale ecological change at a deep Mid-Atlantic hydrothermal vent and reproductive timeseries in the shrimp Rimicaris exoculata. Journal of the Marine Biological Association of the United Kingdom 87, 859-867.

Corbari, L., Zbinden, M., Cambon-Bonavita, M., Gaill, F., Compère, P., (2008). Bacterial symbionts and mineral deposits in the branchial chamber of the hydrothermal vent shrimp Rimicaris exoculata: relationship to moult cycle. Aquatic Biology 1, 225-238.

Cosson, R., Vivier, J., (1997). Interactions of metallic elements and organisms within hydrothermal vents. Cahiers de Biologie Marine 43-50.

Cottin, D., Shillito, B., Chertemps, T., Tanguy, A., Léger, N., Ravaux, J., (2010). Identification of differentially expressed genes in the hydrothermal vent shrimp Rimicaris exoculata exposed to heat stress. Marine Genomics 3, 71-78.

Desbruyères, D., Almeida, A., Biscoito, M., Comtet, T., Kripounoff, A., Le Bris, N., Sarradin, P.-M., Segonzac, M., (2000). A review of the distribution of hydrothermal vent communities along the Northern Mid-Atlantic Ridge: Dispersal vs environmental controls. Hydrobiologia 440, 201-216.

Depledge, M.H., Rainbow, P.S., (1990). Models of regulation and accumulation of trace metals in marine invertebrates. Comparative Biochemistry and Physiology Part C: Comparative Pharmacology 97, 1-7.

Di Giulio, R.T., Benson, W.H., Sanders B.M., Van Veld P.A., (1995) Biochemical mechanisms: Metabolism, adaptation and toxicity. In: Fundamentals of Aquatic Toxicology 2nd, Ed. G.M. Rand. Taylor \& Francis, Washington. pp. 523-561.

Douville, E., Charlou, J.L., Oelkers, E.H., Bienvenu, P., Jove Colon, C.F., Donval, J.P., Fouquet, Y., Prieur, D., Appriou, P., (2002) The Rainbow vent fluids (36 14' N, 
MAR): the influence of ultramafic rocks and phase separation on trace metal content in Mid-Atlantic Ridge hydrothermal fluids. Chemical Geology 184, 37-48.

Edmonds, H.N., German, C.R., Green, D.R.H., Huh, Y., Gamo, T., Edmond, J.M., (1996). Continuation of the hydrothermal fluid chemistry time series at TAG, and the effects of ODP drilling. Geophysical Research Letter 23, 3487-3489.

Engel D., Brouwer M., (1989). Metallothionein and metallothionein-like proteins. Physiological importance. In Advances in Comparative and Environmental Physiology Vol.5, Chapt.3, pp. 53-75, Springer, Berlin.

Erdelmeier, I., Gerard-Monnier, D., Yadan, J. C., Acudiere, J., (1998). Reactions of Nmethyl-2-phenylindole with malondialdehyde and 4-hydroxyalkenals. Mechanistic aspects of the colorimetric assay of lipid peroxidation. Chemical Research Toxicology 11, 1184-1194.

Flohe L., Gunzler W.A., (1984) Assay of glutathione peroxidase. Methods in Enzymology 105, 114-121.

Gaetke, L.M., Chow, C.K., (2003). Copper toxicity, oxidative stress and antioxidant nutrients. Toxicology 189, 147-63.

Gebruk, A.V., Pimenov, N.V., Savvichev, A.S., (1993). Feeding specialization of bresiliid shrimps in the TAG site hydrothermal community. Marine Ecology Progress Series 98, 247-253.

Gena, K., (2013). Deep sea mining of submarine hydrothermal deposits and its possible environmental impact in Manus Basin, Papua New Guinea. Procedia Earth and Planetary Science 6, 226-233.

Geret, F., Riso, R., Sarradin, P.-M., Caprais, J.-C., Cosson, R.P., (2002). Metal bioaccumulation and storage forms in the shrimp, Rimicaris exoculata, from the Rainbow hydrothermal field (Mid-Atlantic Ridge); preliminary approach to the fluid-organism relationship. Cahiers de Biologie Marine 43, 43-52.

Gonzalez-Rey, M., Serafim, A., Company, R., Gomes, T., Bebianno, M.J., (2008). Detoxification mechanisms in shrimp: Comparative approach between hydrothermal vent fields and estuarine environments. Marine Environmental Research 66, 35-37.

Gonzalez-Rey, M., Serafim, A., Company, R., Bebianno, M.J., (2007). Adaptation to metal toxicity: a comparison of hydrothermal vent and coastal shrimps. Marine Ecology 28, 100-107.

Greco, M.A., Hrab, D.I., Magner, W., Kosman, D.J., (1990). Cu, Zn superoxide dismutase and copper deprivation and toxicity in Saccharomyces cerevisiae. Journal of Bacteriology 172, 317-325.

Greenwald, R.A., (1985). Handbook of methods for oxygen radical research. CRC Press, Boca Raton, FL, USA. 
Habig, W.H., Pabst, M.J., Fleischner, G., Gatmaitan, Z., Arias, I.M., Jakoby, W.B., (1974). The identity of glutathione S-transferase B with ligandin, a major binding protein of liver. Proceedings of the National Academy of Sciences 71, 3879-3882.

Hannington, M., Jamieson, J., Monecke, T., Petersen, S., Beaulieu, S., (2011). The abundance of seafloor massive sulfide deposits. Geology 39, 1155-1158.

Halliwell, B., Gutteridge, J., (1984). Oxygen toxicity, oxygen radicals, transition metals and disease. Biochemistry Journal 219, 1-14.

Jan, C., Petersen J., Werner J., Huang S., Teeling H., Glöckner F.O., Golyshina O.V., Dubilier N., Golyshin P.N., Jebbar M., Cambon-Bonavita, M.A., (2014). The gill chamber epibiosis of deep-sea Rimicaris exoculata shrimp revisited by metagenomics and discovery of zetaproteobacterial epibionts. Environmental Microbiology 16, 9, 2723-2738.

Kádár, E., Costa V., Santos. R.S., (2006). Distribution of micro-essential (Fe, Cu, Zn) and toxic $(\mathrm{Hg})$ metals in tissues of two nutritionally distinct hydrothermal shrimps. Science of the Total Environment 358, 143-150.

Li, M., Hu, C., Zhu, Q., Chen, L., Kong, Z., Liu, Z., (2006). Copper and zinc induction of lipid peroxidation and effects on antioxidant enzyme activities in the microalga Pavlova viridis (Prymnesiophyceae). Chemosphere 62, 565-572.

McCord, J.M., Fridovich, I., (1969). Superoxide dismutase: an enzymic function for erythrocuprein (hemocuprein). Journal of Biological Chemistry 244, 6049-6055.

Mestre, N.C., Calado, R., Soares, A.M.V.M., (2014). Exploitation of deep-sea resources: The urgent need to understand the role of high pressure in the toxicity of chemical pollutants to deep-sea organisms. Environmental Pollution 185, 369-371.

Oliveira, C., Almeida, J., Guilhermino, L., Soares, A.M.V.M., Gravato, C., (2012). Acute effects of deltamethrin on swimming velocity and biomarkers of the common prawn Palaemon serratus. Aquatic Toxicology 124-125, 209-216.

Ponsard, J., Cambon-Bonavita, M.-A., Zbinden, M., Lepoint, G., Joassin, A., Corbari, L., Shillito, B., Durand, L., Cueff-Gauchard, V., Compère, P., (2013). Inorganic carbon fixation by chemosynthetic ectosymbionts and nutritional transfers to the hydrothermal vent host-shrimp Rimicaris exoculata. ISME J 7, 96-109.

Pourang, N., Dennis, J.H., Ghourchian, H., (2004). Tissue distribution and redistribution of trace elements in shrimp species with the emphasis on the roles of metallothionein. Ecotoxicology 13, 519-533.

Ravaux, J., Gaill, F., Le Bris, N., Sarradin, P.-M., Jollivet, D., Shillito, B., (2003). Heatshock response and temperature resistance in the deep-sea vent shrimp Rimicaris exoculata. Journal of Experimental Biology 206, 2345-2354. 
Rainbow, P.S., (1998). Phylogeny of trace metal accumulation in crustaceans. In:

Langston W.J. and Bebianno M.J. (Eds). Metal metabolism in aquatic environments. London, Chapmann and Hall, pp. 285-319.

Rieley, G., Van Dover, C.L., Hedrick, D.B., Eglinton, G., (1999). Trophic ecology of Rimicaris exoculata: a combined lipid abundance/stable isotope approach. Marine Biology 133, 495-499.

Roesijadi, G., (1992). Metallothioneins in metal regulation and toxicity in aquatic animals. Aquatic Toxicology 22, 81-114.

Schmidt, C., Corbari, L., Gaill, F., Le Bris, N., (2009). Biotic and abiotic controls on iron oxyhydroxide formation in the gill chamber of the hydrothermal vent shrimp Rimicaris exoculata. Geobiology 7, 454-464.

Schmidt, C., Le Bris, N., Gaill, F., (2008). Interactions of deep-sea vent invertebrates with their environment: the case of Rimicaris exoculata. Journal of Shellfish Research 27, 79-90.

Shillito, B., Gaill, F., Ravaux, J., (2014). The IPOCAMP pressure incubator for deepsea fauna. Journal of Marine Science and Technology 22, 97-102.

Shillito, B., Hamel, G., Duchi, C., Cottin, D., Sarrazin, J., Sarradin, P.M., Ravaux, J., Gaill, F., (2008). Live capture of megafauna from $2300 \mathrm{~m}$ depth, using a newlydesigned pressurised recovery device. Deep-Sea Research I 55, 881-889.

Silva, C., Oliveira, C., Gravato, C., Almeida, J.R., (2013). Behaviour and biomarkers as tools to assess the acute toxicity of benzo(a)pyrene in the common prawn Palaemon serratus. Marine Environmental Research 90, 39-46.

Simpson, S., Angel, B., Hamilton, I., Spadaro, D., Binet, M., (2008). Appendix 7, Water and Sediment Characterisation and Toxicity Assessment for the Solwara 1 Project Environmental Impact Statement in Coffey Natural Systems. Solwara 1 Project Environmental Impact Statement [http://www.nautilusminerals.com/irm/content/environmentreports2.aspx?RID=413]

Van Dover, C.L., (2014). Impacts of anthropogenic disturbances at deep-sea hydrothermal vent ecosystems: A review. Marine Environmental Research 102, $59-72$.

Van Dover, C.L., Fry, B., Grassle, J.F., Humphris, S., Rona, P.A., (1988). Feeding biology of the shrimp Rimicaris exoculata at hydrothermal vents on the MidAtlantic Ridge. Marine Biology 98, 209-216.

Vereshchaka, A., (1997). Comparative morphological studies on four populations of the shrimp Rimicaris exoculata from the Mid-Atlantic Ridge. Deep-Sea Research I 44, 1905-1921. 
Viarengo, A., Burlando, B., Cavaletto, M., Marchi, B., Ponzano, E., Blasco, J., (1999). Role of metallothionein against oxidative stress in the mussel Mytilus galloprovincialis. American Journal of Physiology-Regulatory, Integrative and Comparative Physiology 277, R1612-R1619.

Viarengo, A., Nott, J., (1993). Mechanisms of heavy metal cation homeostasis in marine invertebrates. Comparative Biochemistry and Physiology 104C, 355-372.

Vinagre, C., Madeira, D., Mendonça, V., Dias, M., Roma, J., Diniz, M.S., (2014). Effect of temperature in multiple biomarkers of oxidative stress in coastal shrimp. Journal of Thermal Biology 41, 38-42.

White, S., Rainbow, P., (1985). On the metabolic requirements for Copper and Zinc in Molluscs and Crustaceans. Marine Environmental Research 16, 215-229.

White, S., Rainbow, P., (1982). Regulation and accumulation of copper, zinc and cadmium by the shrimp Palaemon elegans. Marine Ecology Progress Series 8, 101.

Zbinden, M., Shillito, B., Le Bris, N., de Villardi de Montlaur, C., Roussel, E., Guyot, F., Gaill, F., Cambon-Bonavita, M.-A., (2008). New insights on the metabolic diversity among the epibiotic microbial community of the hydrothermal shrimp Rimicaris exoculata. Journal of Experimental Marine Biology and Ecology 359, 131-140.

Zbinden, M., Le Bris, N., Gaill, F., Compére, P., (2004). Distribution of bacteria and associated minerals in the gill chamber of the vent shrimp Rimicaris exoculata and related biogeochemical processes. Marine Ecology Progress Series 284, 237-251.

Zbinden, M., Cambon-Bonavita, M.-A., (2003). Occurrence of Deferribacterales and Entomoplasmatales in the deep-sea Alvinocarid shrimp Rimicaris exoculata gut. FEMS Microbiology Ecology 46, 23-30. 


\section{Figure captions}

Figure 1. Metals concentrations (mean $\pm \mathrm{SD}$ ) in tissues of Rimicaris exoculata for the different treatments. Values followed by the same letter are not significantly different ( $p$ $>0.05$ ) with capital letters for comparison of one tissue between groups and lowercase letters for comparison among one group. Gills (grey), Hepatopancreas (black), Abdominal muscle (white), IS: In situ group, C: Control, $\mathrm{Cu} 1$ : exposed to $0.4 \mu \mathrm{M}, \mathrm{Cu} 2$ : exposed to $4 \mu \mathrm{M}$.

Figure 2. Metallothioneins (MTs, mean $\pm \mathrm{SD}$ ) in tissues of Rimicaris exoculata for the different treatments. Values followed by the same letter are not significantly different ( $p$ $>0.05$ ) with capital letters for comparison of one tissue between groups and lowercase letters for comparison among one group. Gills (grey), Hepatopancreas (black), Abdominal muscle (white), IS: In situ group, C: Control, $\mathrm{Cu} 1$ : exposed to $0.4 \mu \mathrm{M}, \mathrm{Cu} 2$ : exposed to $4 \mu \mathrm{M}$.

Figure 3. Superoxide dismutase (SOD), catalase (CAT), total gluthatione peroxidase (GPx) and gluthatione-S-transferase (GST) activities (mean \pm SD) in tissues of Rimicaris exoculata for the different treatments. Values followed by the same letter are not significantly different $(p>0.05)$ with capital letters for comparison of one tissue between groups and lowercase letters for comparison among one group. Gills (grey), Hepatopancreas (black), Abdominal muscle (white), IS: In situ group, C: Control, Cu1: exposed to $0.4 \mu \mathrm{M}, \mathrm{Cu} 2$ : exposed to $4 \mu \mathrm{M}$. Given the small amount of tissue available for HP, CAT was not analysed. GPx activity was not detected in the abdominal muscle.

Figure 4. Lipid peroxidation (LPO, mean $\pm \mathrm{SD}$ ) in tissues of Rimicaris exoculata for the different treatments. Values followed by the same letter are not significantly different $(p>0.05)$ with capital letters for comparison of one tissue between groups and lowercase letters for comparison among one group. Gills (grey), Hepatopancreas (black), Abdominal muscle (white), IS: In situ group, C: Control, Cu1: exposed to $0.4 \mu \mathrm{M}, \mathrm{Cu} 2$ : exposed to $4 \mu \mathrm{M}$. 


\section{Table captions}

Table 1. Metal concentration (mean \pm SD) in tissues of Rimicaris exoculata and Mirocaris fortunata. Data expressed in $\mu \mathrm{g} . \mathrm{g}^{-1}$ d.w. or $\mu$ mol.g ${ }^{-1}$ w.w.. G: Gills; H: Hepatopancreas; M: Abdominal muscle; S.T.: Soft tissue.

Table 2. Antioxidant enzymes activities (SOD, CAT, GPx, GST) (mean \pm SD) in tissues of the vent shrimp Rimicaris exoculata and coastal shrimps Palaemon elegans, Palaemon serratus, Palaemon varians. G: Gills; H: Hepatopancreas; M: Abdominal muscle; S.T.: Soft tissue.

\section{Supplementary Material}

Table A.1. Metal concentration per tissues (gills, hepatopancreas, muscle) and weighted mean (soft tissue) for Rimicaris exoculata in the different treatments (mean $\pm \mathrm{SD}$ ), expressed in $\mu$ g.g ${ }^{-1}$ d.w.. Values followed by the same letter are not significantly different ( $p>0.05)$ with capital letters for comparison of one tissue between groups and lowercase letters for comparison among one group (for each metal). IS: In situ group; $\mathrm{C}$ : Control; $\mathrm{Cu} 1$ : exposed to $0.4 \mu \mathrm{M}$; $\mathrm{Cu} 2$ : exposed to $4 \mu \mathrm{M}$. 


\section{Table 1.}

\begin{tabular}{|c|c|c|c|c|c|c|c|c|c|}
\hline Species & Sites & Tissues & $\mathbf{C u}$ & Cd & Co & $\mathrm{Fe}$ & Mn & $\mathbf{Z n}$ & References \\
\hline \multirow{15}{*}{$\begin{array}{l}\text { Rimicaris } \\
\text { exoculata }\end{array}$} & \multirow{4}{*}{$\begin{array}{l}\text { TAG } \\
\left(\mu \mathrm{g} \cdot \mathrm{g}^{-1} \text { d.w. }\right)\end{array}$} & $\mathrm{G}$ & $535 \pm 205$ & $1.24 \pm 0.91$ & $3 \pm 2$ & $6201 \pm 4299$ & $26 \pm 11$ & $277 \pm 123$ & \multirow[t]{4}{*}{ this study } \\
\hline & & $\mathrm{H}$ & $1562 \pm 592$ & $8.32 \pm 1.68$ & $3.7 \pm 1.7$ & $6122 \pm 1764$ & $29 \pm 10$ & $94 \pm 64$ & \\
\hline & & M & $98 \pm 23$ & $0.15 \pm 0.03$ & $0.3 \pm 0.1$ & $1052 \pm 307$ & $6 \pm 2$ & $88 \pm 39$ & \\
\hline & & S.T. & $379 \pm 146$ & $1.3 \pm 0.4$ & $1.6 \pm 0.3$ & $2740 \pm 1191$ & $16 \pm 3.5$ & $112 \pm 31$ & \\
\hline & \multirow[t]{4}{*}{ ( $\mu$ mol.g ${ }^{-1}$ w.w. $)$} & G & $0.75 \pm 0.18$ & $0.3210^{-3} \pm 0.110^{-3}$ & $3.110^{-3} \pm 510^{-4}$ & $3.6 \pm 1.1$ & $0.022 \pm 0.004$ & $0.22 \pm 0.06$ & \multirow[t]{4}{*}{ this study } \\
\hline & & $\mathrm{H}$ & $2.51 \pm 0.78$ & $8.710^{-3} \pm 2.110^{-3}$ & $5.610^{-3} \pm 210^{-4}$ & $12.9 \pm 2.6$ & $0.06 \pm 0.02$ & $0.24 \pm 0.09$ & \\
\hline & & M & $0.11 \pm 0.02$ & $0.110^{-3} \pm 0.0310^{-3}$ & $0.510^{-3} \pm 110^{-4}$ & $1.5 \pm 0.4$ & $0.008 \pm 0.002$ & $0.13 \pm 0.02$ & \\
\hline & & S.T. & $0.32 \pm 0.18$ & $0.0008 \pm 0.0003$ & $0.002 \pm 0.0016$ & $2.8 \pm 1.5$ & $0.02 \pm 0.01$ & $0.13 \pm 0.04$ & \\
\hline & \multirow{3}{*}{$\begin{array}{l}\text { Rainbow } \\
\left(\mu \mathrm{mol} . \mathrm{g}^{-1} \text { w.w. }\right)\end{array}$} & G & $1.2 \pm 0.6$ & $0.014 \pm 410^{-3}$ & - & $25.5 \pm 11.4$ & $0.316 \pm 0.18$ & $17.9 \pm 5.0$ & \multirow{3}{*}{$\begin{array}{l}\text { Geret et al. } \\
2002\end{array}$} \\
\hline & & $\mathrm{H}$ & $0.61 \pm 0.21$ & $3.510^{-3} \pm 910^{-4}$ & - & $24.6 \pm 1.8$ & $0.076 \pm 0.009$ & $5.7 \pm 1.7$ & \\
\hline & & M & $0.26 \pm 0.08$ & $1.110^{-3} \pm 910^{-4}$ & - & $3.1 \pm 1.86$ & $0.039 \pm 0.026$ & $1.5 \pm 1.1$ & \\
\hline & \multirow{3}{*}{$\begin{array}{l}\text { Rainbow } \\
\left(\mu \mathrm{g} . \mathrm{g}^{-1} \text { d.w. }\right)\end{array}$} & $\mathrm{G}$ & $1060 \pm 200$ & - & - & $90460 \pm 48600$ & - & $2900 \pm 400$ & \multirow{3}{*}{$\begin{array}{l}\text { Kádár et al. } \\
2006\end{array}$} \\
\hline & & $\mathrm{H}$ & $700 \pm 200$ & - & - & $6640 \pm 2230$ & - & $800 \pm 700$ & \\
\hline & & M & $300 \pm 160$ & - & - & $610 \pm 260$ & - & $300 \pm 100$ & \\
\hline & $\begin{array}{l}\text { Rainbow } \\
\left(\mu \mathrm{g} \cdot \mathrm{g}^{-1} \text { d.w. }\right)\end{array}$ & S.T. & $176.7 \pm 74$ & $0.49 \pm 0.02$ & - & $2122 \pm 867$ & $43.2 \pm 10.4$ & $209 \pm 111$ & $\begin{array}{l}\text { Gonzalez-Rey } \\
\text { et al. } 2008\end{array}$ \\
\hline \multirow{6}{*}{$\begin{array}{l}\text { Mirocaris } \\
\text { fortunata }\end{array}$} & Rainbow & G & $1700 \pm 500$ & - & - & $122970 \pm 41600$ & - & $4300 \pm 800$ & \multirow{3}{*}{$\begin{array}{l}\text { Kádár et al. } \\
2006\end{array}$} \\
\hline & ( $\mu$ g.g $\mathrm{g}^{-1}$ d.w.) & $\mathrm{H}$ & $400 \pm 100$ & - & - & $3010 \pm 620$ & - & $600 \pm 100$ & \\
\hline & & M & $200 \pm 60$ & - & - & $940 \pm 240$ & - & $200 \pm 40$ & \\
\hline & \multirow{3}{*}{$\begin{array}{l}\text { Lucky Strike } \\
\left(\mu \mathrm{g} . \mathrm{g}^{-1} \text { d.w.) }\right.\end{array}$} & G & $1400 \pm 500$ & - & - & $44170 \pm 15320$ & - & $1900 \pm 800$ & \multirow{3}{*}{$\begin{array}{l}\text { Kádár et al. } \\
2006\end{array}$} \\
\hline & & $\mathrm{H}$ & $500 \pm 200$ & - & - & $1870 \pm 250$ & - & $900 \pm 600$ & \\
\hline & & M & $40 \pm 10$ & - & - & $190 \pm 80$ & - & $60 \pm 30$ & \\
\hline
\end{tabular}


Table 2.

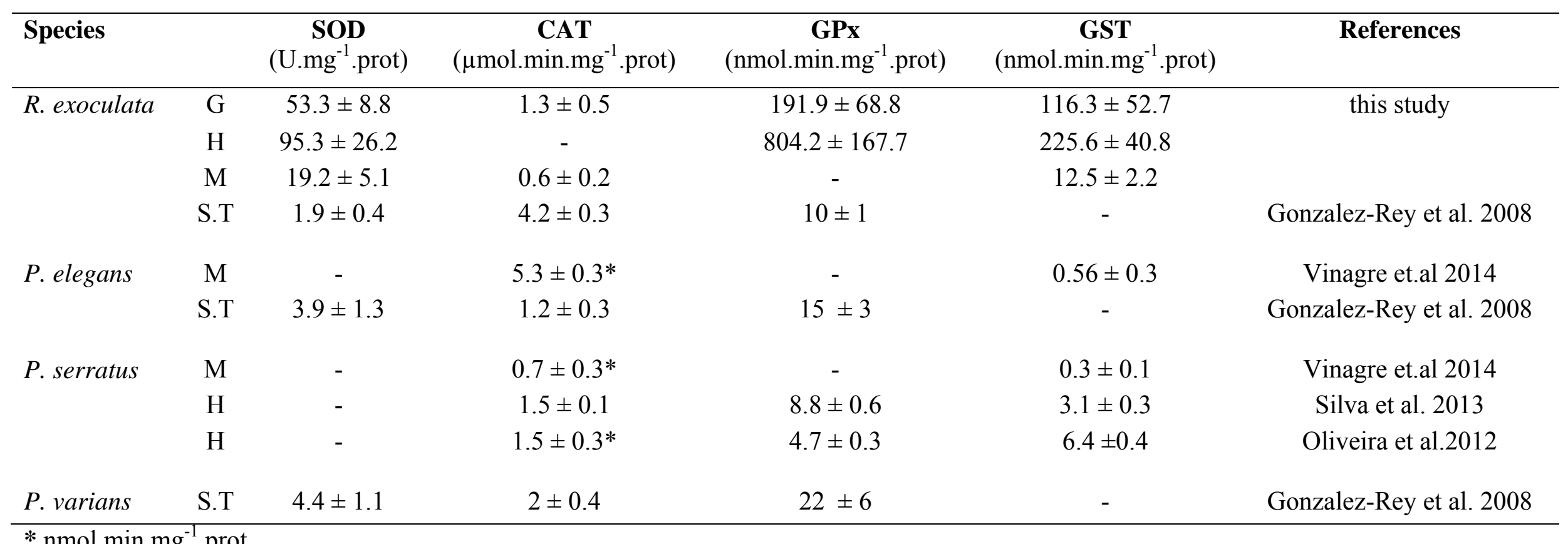


Figure 1
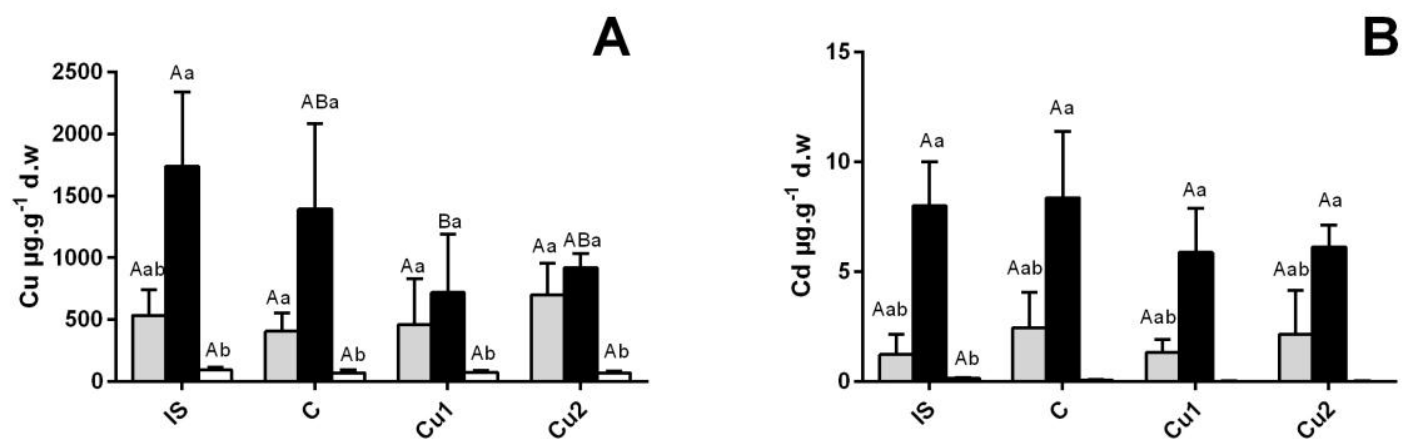

C
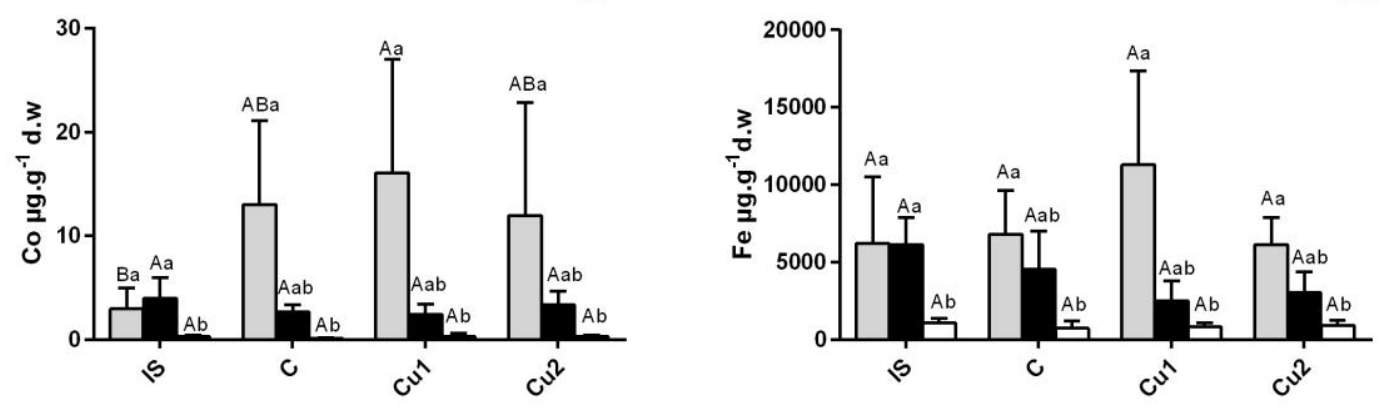

E

F
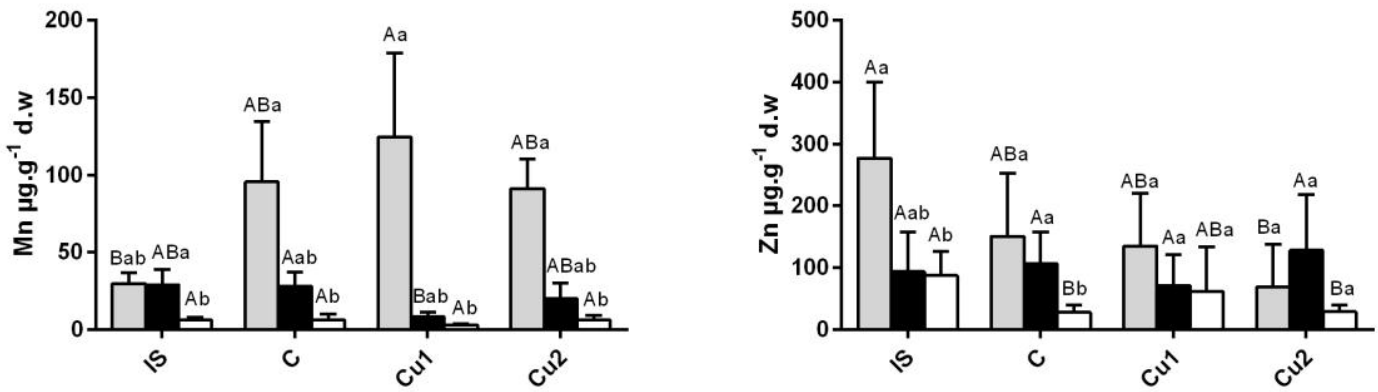
Figure 2

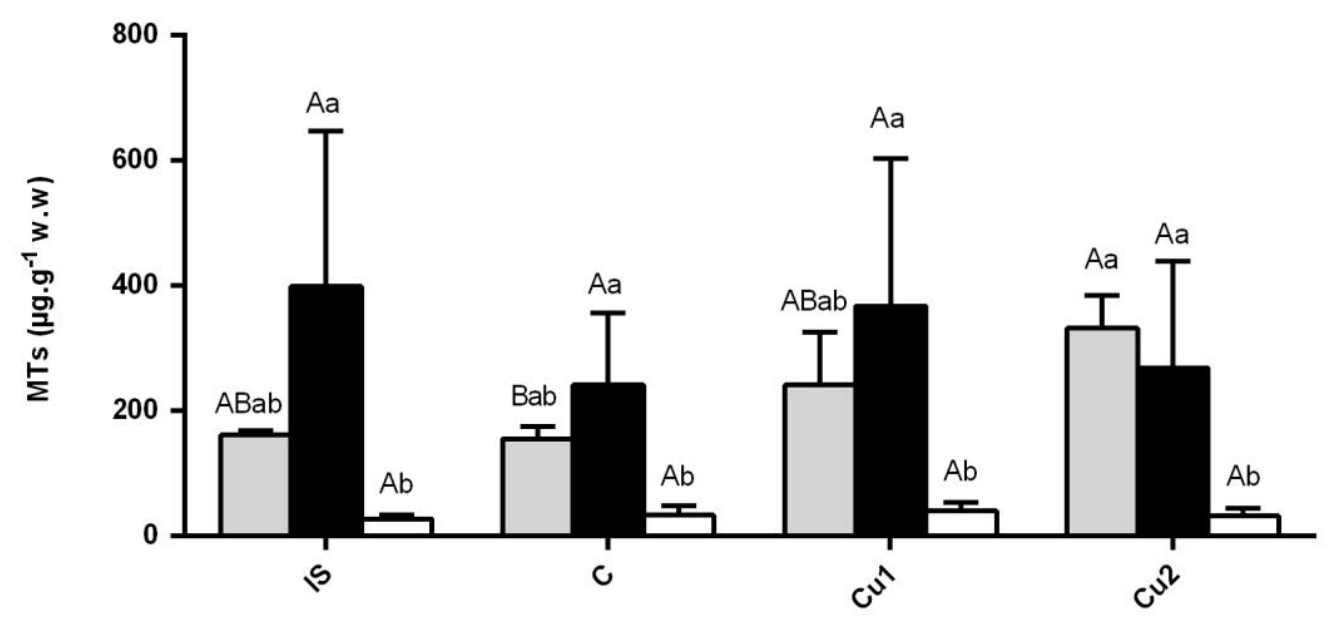

Figure 3
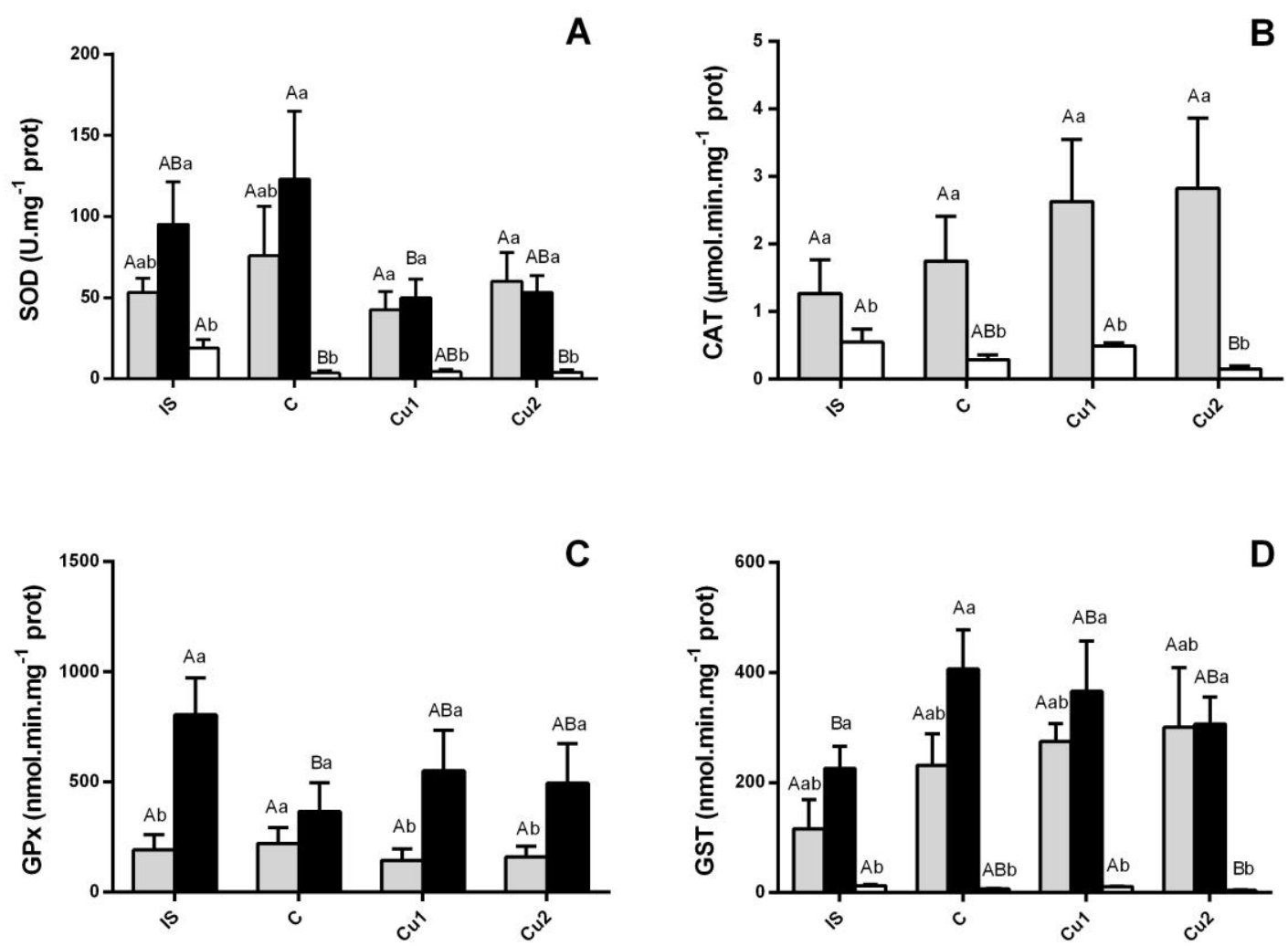
Figure 4

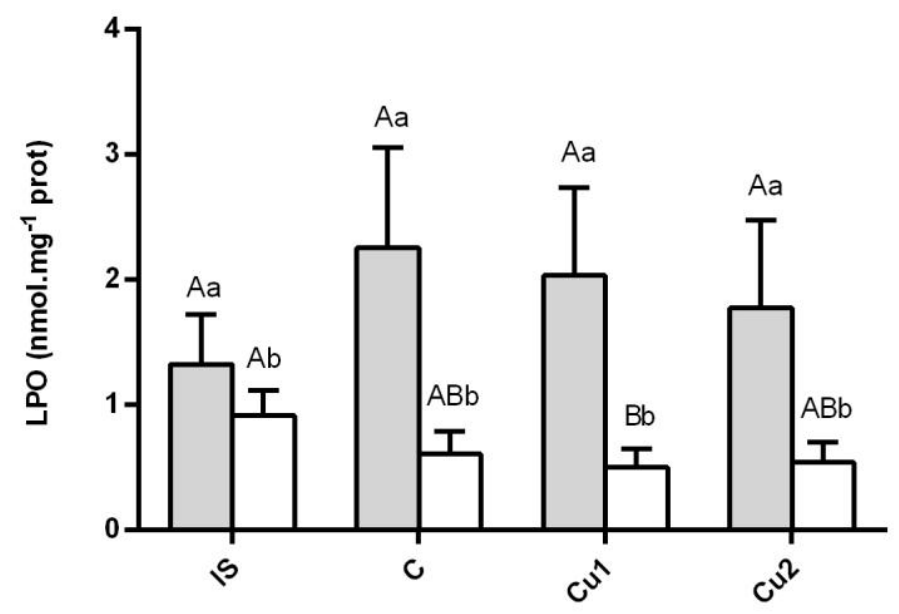


Table A.1.

\begin{tabular}{clcccc}
\hline \multicolumn{1}{c}{ Gills } & $\mathrm{IS}$ & $\mathbf{C}$ & $\mathbf{C u} \mathbf{1}$ & $\mathbf{C u 2}$ \\
& $\mathrm{Cd}$ & $535 \pm 205^{\mathrm{Aab}}$ & $408 \pm 145^{\mathrm{Aa}}$ & $461 \pm 369^{\mathrm{Aa}}$ & $700 \pm 258^{\mathrm{Aa}}$ \\
& $\mathrm{Co}$ & $3 \pm 2^{\mathrm{Aab}}$ & $2 \pm 1.6^{\mathrm{Aab}}$ & $1 \pm 0.6^{\mathrm{Aab}}$ & $2.2 \pm 2^{\mathrm{Aab}}$ \\
& $\mathrm{Fe}$ & $6201 \pm 4299^{\mathrm{Aa}}$ & $6791 \pm 288^{\mathrm{ABa}}$ & $16 \pm 11^{\mathrm{Aa}}$ & $12 \pm 10.9^{\mathrm{ABa}}$ \\
& $\mathrm{Mn}$ & $30 \pm 7^{\mathrm{Bab}}$ & $96 \pm 39^{\mathrm{ABa}}$ & $1285 \pm 6051^{\mathrm{Aa}}$ & $6129 \pm 1751^{\mathrm{Aa}}$ \\
& $\mathrm{Zn}$ & $277 \pm 123^{\mathrm{Aa}}$ & $151 \pm 102^{\mathrm{ABa}}$ & $135 \pm 85^{\mathrm{ABa}}$ & $91 \pm 19^{\mathrm{ABa}}$ \\
\hline Hepato- & $\mathrm{Cu}$ & $1740 \pm 600^{\mathrm{Aa}}$ & $1395 \pm 690^{\mathrm{ABa}}$ & $719 \pm 474^{\mathrm{Ba}}$ & $919 \pm 115^{\mathrm{ABa}}$ \\
pancreas & $\mathrm{Cd}$ & $8 \pm 2^{\mathrm{Aa}}$ & $8 \pm 3^{\mathrm{Aa}}$ & $6 \pm 2^{\mathrm{Aa}}$ & $6 \pm 1^{\mathrm{Aa}}$ \\
& $\mathrm{Co}$ & $3.7 \pm 2^{\mathrm{Aa}}$ & $2.7 \pm 0.7^{\mathrm{Aab}}$ & $2 \pm 0.9^{\mathrm{Aab}}$ & $3.4 \pm 1.3^{\mathrm{Aab}}$ \\
& $\mathrm{Fe}$ & $6122 \pm 1764^{\mathrm{Aa}}$ & $4541 \pm 2466^{\mathrm{Aab}}$ & $2488 \pm 1297^{\mathrm{Aab}}$ & $3046 \pm 1331^{\mathrm{Aab}}$ \\
& $\mathrm{Mn}$ & $29 \pm 10^{\mathrm{ABa}}$ & $28 \pm 9^{\mathrm{Aab}}$ & $8 \pm 3^{\mathrm{Bab}}$ & $20 \pm 10^{\mathrm{Aab}}$ \\
& $\mathrm{Zn}$ & $94 \pm 64^{\mathrm{Aab}}$ & $107 \pm 51^{\mathrm{Aa}}$ & $72 \pm 50^{\mathrm{Aa}}$ & $128 \pm 90^{\mathrm{Aa}}$ \\
\hline Muscle & $\mathrm{Cu}$ & $94 \pm 22^{\mathrm{Ab}}$ & $71 \pm 24^{\mathrm{Ab}}$ & $75 \pm 17^{\mathrm{Ab}}$ & $72 \pm 15^{\mathrm{Ab}}$ \\
& $\mathrm{Cd}$ & $0.15 \pm 0.03^{\mathrm{Ab}}$ & $0.06 \pm 0.05^{\mathrm{ABb}}$ & $0.02 \pm 0.02^{\mathrm{Bb}}$ & $0.01 \pm 0.03^{\mathrm{Bb}}$ \\
& $\mathrm{Co}$ & $0.34 \pm 0.1^{\mathrm{Ab}}$ & $0.13 \pm 0.09^{\mathrm{Ab}}$ & $0.34 \pm 0.26^{\mathrm{Ab}}$ & $0.3 \pm 0.1^{\mathrm{Ab}}$ \\
& $\mathrm{Fe}$ & $1052 \pm 307^{\mathrm{Ab}}$ & $724 \pm 490^{\mathrm{Ab}}$ & $813 \pm 245^{\mathrm{Ab}}$ & $906 \pm 349^{\mathrm{Ab}}$ \\
& $\mathrm{Mn}$ & $6.3 \pm 1.6^{\mathrm{Ab}}$ & $6.2 \pm 4^{\mathrm{Ab}}$ & $3 \pm 0.8^{\mathrm{Ab}}$ & $6.5 \pm 2.6^{\mathrm{Ab}}$ \\
& $\mathrm{Zn}$ & $88 \pm 39^{\mathrm{Ab}}$ & $28 \pm 12^{\mathrm{Bb}}$ & $62 \pm 72^{\mathrm{ABa}}$ & $29 \pm 11^{\mathrm{Ba}}$ \\
\hline Soft tissue & $\mathrm{Cu}$ & $379 \pm 146^{\mathrm{A}}$ & $331 \pm 154^{\mathrm{A}}$ & $265 \pm 98^{\mathrm{A}}$ & $277 \pm 61^{\mathrm{A}}$ \\
& $\mathrm{Cd}$ & $1.3 \pm 0.4^{\mathrm{A}}$ & $1.4 \pm 0.3^{\mathrm{A}}$ & $1.3 \pm 0.45^{\mathrm{A}}$ & $1.5 \pm 0.7^{\mathrm{A}}$ \\
& $\mathrm{Co}$ & $1.1 \pm 0.3^{\mathrm{A}}$ & $3.4 \pm 2^{\mathrm{A}}$ & $3.5 \pm 1.7^{\mathrm{A}}$ & $2.9 \pm 1.5^{\mathrm{A}}$ \\
& $\mathrm{Fe}$ & $2740 \pm 1191^{\mathrm{A}}$ & $2342 \pm 1041^{\mathrm{A}}$ & $3757 \pm 1547^{\mathrm{A}}$ & $2340 \pm 810^{\mathrm{A}}$ \\
& $\mathrm{Mn}$ & $11 \pm 3.4^{\mathrm{A}}$ & $30 \pm 20^{\mathrm{A}}$ & $30 \pm 22^{\mathrm{A}}$ & $32 \pm 15^{\mathrm{A}}$ \\
& $\mathrm{Zn}$ & $112 \pm 31^{\mathrm{A}}$ & $63 \pm 29^{\mathrm{AB}}$ & $85 \pm 53^{\mathrm{AB}}$ & $49 \pm 14^{\mathrm{B}}$ \\
\hline & & & &
\end{tabular}




\section{Graphical Abstract}

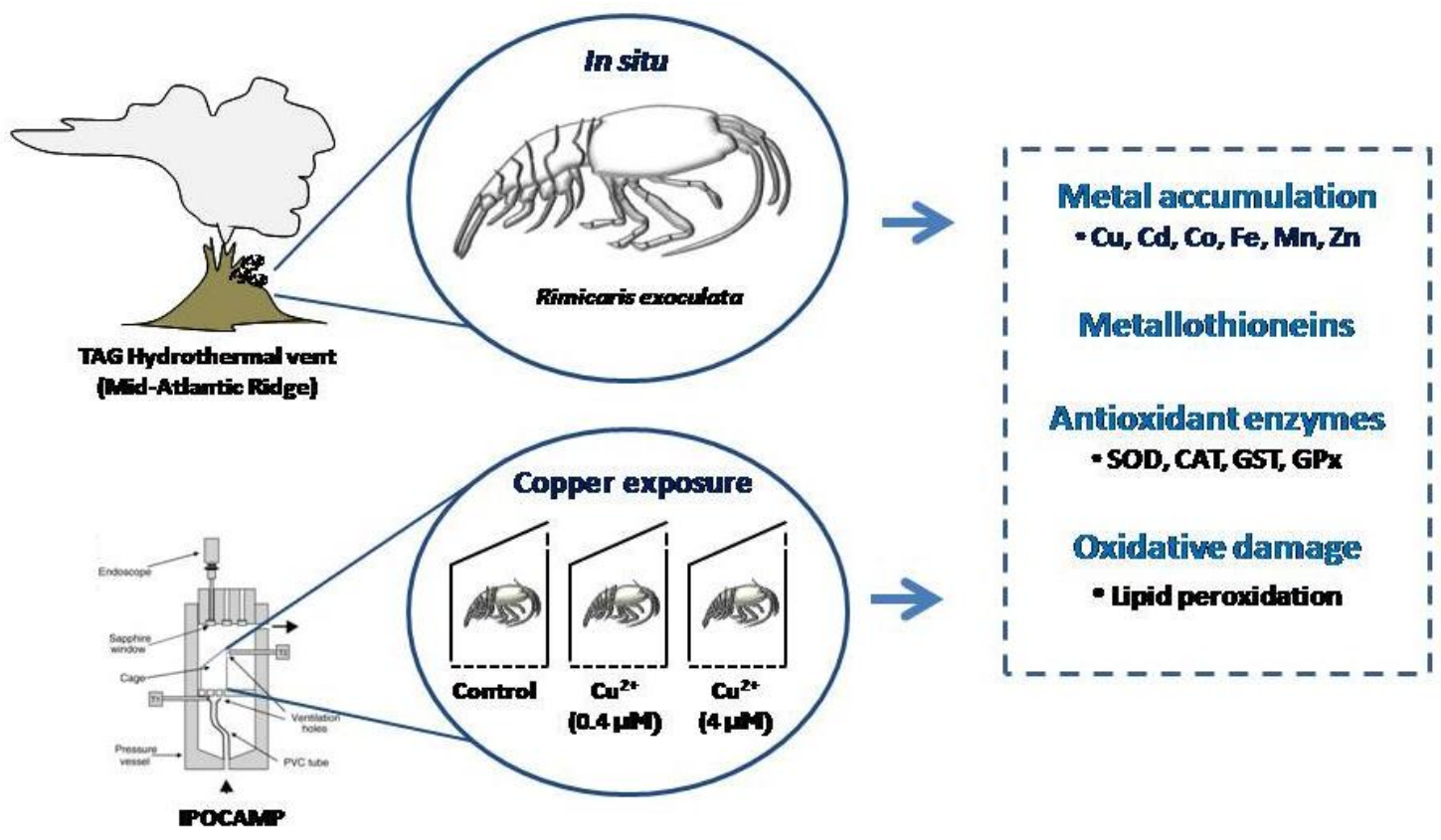

